\title{
The Cities in East Sumatera after the Development of Plantation Industry 1863-1942
}

\author{
Edi Sumarno $^{1}$, Nina Karina ${ }^{1}$, Junita Setiana Ginting ${ }^{1}$, Handoko $^{1}$ \\ ${ }^{1}$ University of Sumatera Utara \\ edisumarno64@gmail.com
}

\begin{abstract}
The ports in East Sumatra were located on the banks of the riverbefore the presence of plantations.These traditional cities underwent some changes after the presence of plantations, where the cities on the riverbank changed intothe cities in the middle of the plantation. The new cities that emerged after the development of plantations were formed or initiated by the plantation party and the Dutch Colonial government in East Sumatra. The purpose was for the cities to become the administrative center of the plantations and government. Why did the colonial government or plantations build new cities? And howwas the development of the old cities and the new cities?
\end{abstract}

Keywords : city; plantation; East Sumatera

\section{Introduction}

Some ports were built in the attempt to centralize the trade and political activities before the plantations developed in East Sumatra. The city or port was the center of the traditional government of the Malay Sultanate in East Sumatra. Trading activities built due to the trade relations between the inland and the coastal people. The increasingly crowded activities led to the formation of political unity headed by the most influential person and entitled to the excise of goods traded in the region. This political unity was later called Malay Sultanate. This kind of unity could later be found in other regions in East Sumatra. ${ }^{1}$

These ports or "traditional port cities" continued to develop in line with the development of the Malay Sultanate in East Sumatra. These ports were Tanjung Pura in Langkat Sultanate, Labuhan in Deli Sultanate, Rantau Panjang in Serdang Sultanate, Tanjung Beringin in Bedaga iKingdom, Bandar Khalifah in Padang Kingdom, Tanjung Balai in Asahan Sultanate, and Siak Sri Indra pura in Siak Sultanate. ${ }^{2}$ However, some of these ports underwent some changes after plantations developed in East Sumatra. Many cities were deliberately builtnext to the plantation centers.

\section{Methodology}

The technique of collecting primary and secondary data wasconducted through observation or direct survey to the object of research while the supporting data were gathered from libraries and institutions, for instance National Archive of Indonesia,National Library of Indonesia, Tengku Lukman Sinar Library; this step was carried out to collect archives, books, publications / magazines and others related to cities in East Sumatra. The supporting data were obtained from direct visits or field observations by visiting old cities and new cities formed after the plantations in East Sumatra. After the data collection was complete, the next step was to verify the data that had been obtained and constructed it into a complete writing.

\footnotetext{
1 J. Kathirittamby-Wells, "Hulu-hilir Unity and Conflict: Malay Statecraft inEast Sumatra before the MidNineteenth Century", dalamArchipe1, 1993, pg. 77-96.

2 Edi Sumarno, "Mundurnya Kota Pelabuhan Tradisional di Sumatera Timur pada Periode Kolonial" dalam Historisme Edisi NO.22/Tahun XI/Agustus 2006, pg. 4-5.
} 


\section{Discussion}

\subsection{Malay Traditional Port in East Sumatera}

The ports in East Sumatra that had established relations with the VOC in Malacca in the $17^{\text {th }}$ and $18^{\text {th }}$ century were Asahan, Batubara, and Deli. Many ships harbored in those ports to set up trade relationship. ${ }^{3}$ After the VOC was declared bankrupt, many traders from the east coast of Sumatra traded to PinangIsland in the early of $19^{\text {th }}$ century. On account of that matter, the British governor on Pinang Island ordered envoys to visit and observe the community, government and trade on the east coast of Sumatra. Ibbetson's reports regarding the east coast of Sumatra were considered inaccurate; therefore the British government in Malaya sent John Andersonas a new envoy in 1823. In his assignment letter, Anderson was required to visit the Sultan Kejeruan Muda in Langkat, Sultan Panglima in Deli, Sri Sultan Ahmat in Bulu Cina, Sultan Besar from Serdang, treasurer in Batubara, Yang di Pertuan Asahan, and Sultan of Siak. ${ }^{4}$

Anderson's report illustrated how traditional cities or Malay ports on the East Coast of Sumatra, though still very simple, but they already had social, cultural, economic and political structures. Hementioned that each city had a ruler who had the right to the excise or tax from the merchants, either from the goodsor the harbored ships. The ports were also close to the palace or the ruler's residence and most of the people's houses were on the banks of the river. There was also a market where theytraded with people from other regions.

One of the references used to identify the traditional Malay cities in East Sumatra was Anderson's report (1823). He made an overview or description of each region he visited, including Deli, Serdang, Batubara, Asahan and Bilah.Based on his report, the structure of the centers of power of the Malay Kingdom or the traditional city of the Malay Kingdom consisted of the palace, the city or port as well as a fairly dense settlement. ${ }^{5}$ Some of the areas he visited had been categorized as traditional cities or ports, for instance Labuhan in Deli, Tanjung Pura and Pangkalan Bubunin Langkat, Rantau Panjangin Serdang, Kampung Bogain Batubara, Kampung Balei (Tanjung Balai) in Asahan, and some villages in Southern Asahan, all of which had the centers of power as well as ports. ${ }^{6}$

The first port that Anderson visited was Langkat to meet Sultan KejeruanMuda. According to his report, the most crowded ports in Langkat were Kwala Bubun or Pangkalan Bubun and $\mathrm{T}$ anjung Pura where all of them located in Langkat River or Batang Serangan River. There were many houses and a market with pepper as the main commodity. He then met Sultan Panglima as the ruler of Labuhan Deli (Deli) on January 16, 1823. Labuhan Deli itself was located half a mile downstream from the estuary of Deli River. ${ }^{7}$ The name 'Labuhan' was closely related to 'Labuhan (harbor) River' which meant a place to harbor

\footnotetext{
3 Ahmad Jaelani Halimi, Perdagangan dan Perkapalan Melayu di Selat Malaka Abad ke-15 hingga ke-18, Kuala Lumpur: Dewan Bahasa dan Pustaka, 2006, pg. 224.

${ }^{4}$ Karl J. Pelzer, Toean Keboen dan Petani: Politik Kolonial dan Perjuangan Agraria di Sumatera Timur 1863 1947, (terj. J. Rumbo) Jakarta: Sinar Harapan Publisher, 1985, pg. 17.

5 John Anderson, Mission to East Coast of Sumatera in 1823, Kuala Lumpur/Singapore/New York/London: Oxford University Press, 1971.

${ }^{6}$ John Anderson, Acheen and the Port on the North and East Coast Sumatra, London: Wm. H. Allen \& Co. Leadenhall Street, 1840.

${ }^{7}$ P. J. Veth, "Het Lanschap Deli op Sumatra”, TNAG, Deel II, 1877, pg. 153.
} 
which was also the other name of Deli River. ${ }^{8} \mathrm{He}$ first visited Kampung Bogawhere the ruler of Batubara lived,when he was in Batubara. There were at least 300 houses in this village.

\subsection{The Modern City "Onderneming" in East Sumatera}

The colonial government built the new cities, either as the administrativecenter, economiccenter, or even as the backbone of periphery which was the ondernemingspread out in the inland areas. The colonial cities were usually built on the crossings of highways, railways, and river. For instance, Medan which was initially built from Deli Maatschappij office in 1880 on the banks of the Deli River close to the train station and the highway leading to Belawan. Medan then developed into the main city in the Residency of East Sumatra. The other colonial cities were later built with almost the same pattern, like Binjai, Tebing Tinggi, Kisaran, Pematang Siantar, and Rantau Prapat, in addition to other small cities such as Lubuk Pakam, Sungai Rampah, Pancur Batu, Bangun Purba, and many more.

The presence of colonial cities in strategic places where most of which caused by the construction of highways and railways, had major implications for the formation of the traditional port cities. The cutting of traditional lines with rivers as the main base of transportation resulted in the changes of trade routes. Rivers played major roles before the construction of highways and railways, where all economic activities followed the river flow, but then the roles were mostly taken over by land transportation. It was known that the source of income for traditional rulers was its hegemony over the river, where economic activity mainly took place. As a result, the economic profits slowly diminished and the role of traditional rulers began to fade. Along with it, some traditional cities experienced setbacks, some of which even moved their centers of power close to the newly built colonial cities. For instance, Deli Sultanate, which was originally in Labuhan in the downstream of the Deli River to a more upstream area in Medan Putri area in 1887, moved to be close to the newly developed Medan City. Afterwards, Labuhan then suffered a setback. ${ }^{9}$

In another place, Sultan Serdang also had to move his palace from RantauPanjang in the downstreamof the Ular River, although not to LubukPakam, but to a more upstream areaof GaluhPerbaungan City in $1886 .{ }^{10}$ Along with it, the abandoned RantauPanjang also lost its ground. King Padang also had to move his center of power from the downstream of Bandar Khalifah to the upstream of Padang River in Bandar Sakti, Tebing Tinggi, where the center of power 'onder-afdeling' of Padang Bedagai was located.In Bedagai Kingdom, although the palace remained in the downstream of TanjungBeringin, the office was moved to Firdaus, Sungai Rampah, in the late 1920s about $6 \mathrm{~km}$ upstream from TanjungBeringin. Unfortunately, it also led to the setback of Tanjung Beringin port. ${ }^{11}$

\section{Conclusion}

From the description above, it can be concluded that the construction of land tracks, for instance roads and railways in East Sumatra as part of the economic expansion of plantations, had a major influence on the existence of "traditional port cities" in East Sumatra. It might have different kind of influence, but it is undeniable that it was indeed affected by the

\footnotetext{
${ }^{8}$ Ratna, "Labuhan Deli: RiwayatmuDulu”, inJurnalHistorisme, Ed. No. 22/Year XI/August 2006, pg. 7.

9 T. L. Sinar, Sari SejarahSerdang, Vol. 2, Jakarta: Department of P\&K, 1986, pg. 38.

${ }^{10}$ Wan Syaifuddin, ed., KronikMahkotaKesultananSerdang, Medan: YandiraAgung, 2003, pg. 33.

${ }^{11}$ Edi Sumarno, "Mundurnya Kota Pelabuhan Tradisional di Sumatera Timur pada Periode Kolonial" dalam Historisme Ed. NO.22/Year XI/August 2006, pg. 4-5.
} 
construction of land tracks. It appeared that the "port cities" where the land tracks were built, which was then followed by the formation of new colonial cities, suffered major setbacks. This happened to Labuhan as the traditional port city of Deli Sultanate, Rantau Panjang, the traditional port city of Serdang Sultanate, Tanjung Beringin, the traditional port city of Bedagai Sultanate, and Bandar Khalifah, the traditional port city of Padang Kingdom. On the other hand, in the areas where the construction of land trackswere relatively small or none at all, for instance in the southern part of Asahan and the entire Bengkalis area, river transportation remained the main transportation route. In these areas, the traditional port cities persisted. This happened to the traditional port city of Labuhan Bilik in onder-afdeling Labuhan Batu Bagan Siapi-api, Pekanbaru, Siak Sri Indrapura, and Bengkalis in afdeling Bengkalis. However, a completely different pattern happened toTanjung Balai and Tanjung Pura. These traditional port cities remained persisted even though land tracks had also been built in both cities. TanjungBalai was retained by the Asahan Sultanate as the center of its administration was solely because it was also the center of the afdeling Asahan government. Meanwhile, Tanjung Pura was maintained because the Sultan of Langkat was reluctant to move it to Binjai.This reluctance was likely because Binjaiwas not located close to the same river as Tanjung Pura.

\section{References}

Anseb, 1938, De Grond van Deli, Medan: Varekamp \& Co.

Anderson, John, 1840, Acheen and the Port on the North and East Coast Sumatra, London: Wm. H. Allen \& Co. Leadenhall Street.

Anderson, John, 1971,Mission to East Coast of Sumatera in 1823, Kuala Lumpur/Singapore/New York/London: Oxford University Press.

Broersma, R.,1992, Oostkust van Sumatra: De Ontwikkeling van het Gewest, deel II, The Hague: Charles Dixon Deventer.

Halimi, Ahmad Jaelani, 2007, Perdagangan dan Perkapalan Melayu di Selat Malaka Abad ke-15 hingga ke-18, Kuala Lumpur: Dewan Bahasa dan Pustaka.

Indera, 1996, "PertumbuhandanPerkembangan Deli Spoorweg Maatschappij, 1883-1940" Tesis $S$-2, unpublished, Depok: University of Indonesia.

Kathirittamby-Wells, J., "Hulu-hilir Unity and Conflict: Malay Statecraft inEast Sumatra before the Mid-Nineteenth Century", dalamArchipel, 1993.

Pelzer, Karl J., 1985,Toean Keboendan Petani: Politik Kolonial dan Perjuangan Agraria di Sumatera Timur 1863-1947, (trans. J. Rumbo) Jakarta: PenerbitSinarHarapan.

Ratna, "Labuhan Deli: Riwayatmu Dulu", dalam Jurnal Historisme, Ed. No. 22/Year XI/August 2006.

Said, Mohammad, 1977, Koelin Kontrak Tempoe Doeloe: dengan Deritadan Kemarahannya, Medan: Waspada.

Sinar, T. L., 1986, Sari Sejarah Serdang, Jilid 2, Jakarta: Departemen P\&K.

Stoler, Ann Laura, 2005,Kapitalisme dan Konfrontasi di Sabuk Perkebunan Sumatera (1870 1979), Yogyakarta: Karsa.

Sumarno, Edi, "Mundurnya Kota Pelabuhan Tradisional di Sumatera Timur pada Periode Kolonial” inHistorisme Ed. NO.22/Year XI/August 2006.

Syaifuddin, Wan, ed., 2003, Kronik Mahkota Kesultanan Serdang, Medan: Yandira Agung.

Veth, P. J., "Het Lanschap Deli op Sumatra", TNAG, Deel II, 1877. 
Volker, T.,1918, Van Oerbosch Tot Cultuurgebied: EenSchetsvan de Beteekenis van de Tabak, de Andere Cultures, en de IndustrieterOostkust van Sumatra, Medan, De Deli Planters Vereeniging.

Wie, Thee Kian, 1977, Plantation Agriculture and Export Growth an Economic History of East Sumatra 1863-1942. Jakarta: National of Institute of Economic and Social Research (LEKNAS - LIPI). 